\title{
Revisão dos Conceitos de Autoridade, Autorização, Permissão, Direito Subjetivo e Norma Juridica*.
}

\author{
Goffredo Telles Júnior
}

\author{
Catedrático e Professor Titular do Departamento de \\ Filosofia e Teoria Geral do Direito, da Universidade \\ de São Paulo, Faculdade de Direito
}

\begin{abstract}
SUMÁrIo: 1. Capacidades de fato: Comuns e especiais. 2. Definição de autoridade. Estado e situação das pessoas. 3. e 4. Autoridade-poder e autoridade-pessoa. 5. O ato de autorizar: delegação de autoridade. Os dois sentidos da palavra autorização. 6. Diferença entre autorização e permissão. 7. Emprego impróprio da palavra autorização em muitos textos legais. 8. A norma jurídica: ínico meio para a concessão das permissões jurídicas. 9. Permissões explícitas e implícitas. 10. O Princípio da Legalidade: fundamento das permissōes jurídicas. 11. Permissāo dada por meio de norma jurídica: definição do Direito Subjetivo. 12. Difereņ̧a entre faculdade e capacidade. 13 e 14 . O Direito de fazer e ter, e o Direito de defender Direitos. 15. Imperativo autorizante: definição da norma jurídica. 16. Autorizamento e autorização. 17. Atributividade: não define a norma jurídica.
\end{abstract}

\section{$\S 1$.}

As capacidades de fato se dividem em capacidades comuns e capacidades especiais.

São capacidades comuns as capacidades de fato de que são titulares todas as pessoas, com excepção, obviamente, das pessoas que a lei qualifica de incapazes (absolutamente e relativamente incapazes). São comuns, portanto, as capacidades de fato na generalidade dos homens, sem consideração pelas suas qualificações específicas.

Constituem capacidades comuns, por exemplo, as capacidades de ir e vir, estabelecer residência, casar, ser empregado

* Este trabalho é parte de trabalhos mais extensos, escritos para a Enciclopédia Saraiva de Direito. 
ou empregador, comprar e vender, doar e legar, outorgar procuração e ser mandatário, ser herdeiro e legatário.

São capacidades especiais as capacidades de fato das pessoas enquanto pertencentes a uma categoria legalmente qualificada, em razão de seu estado ou de sua situação.

Constituem capacidades especiais, por exemplo, as capacidades do marido, para exercer a chefia da sociedade conjugal; do pai, para exercer o pátrio poder; do proprietário, para usar, fruir e dispor de seus bens; do médico, para exercer a medicina; do juiz, para decidir os pleitos; do delegado de polícia, para a perseguição dos delinqüentes; do Presidente da República, para exercer a direção superior da administração federal; da sociedade mercantil, para o exercício do comércio; do sindicato, para promover a conciliação, nos dissídios de trabalho; da sociedade global, como comunidade, para exercer, pelos meios legais, coação sobre os violadores das normas jurídicas, a fim de fazer cessar ou de obstar a infringência.

\section{$\S 2$.}

Nos domínios do Direito, as capacidades especiais são o fundamento da autoridade.

Autoridade, para o Direito, é o poder pelo qual uma pessoa ou entidade se impõe às outras, em razão de seu estado ou situação. É o poder de Direito de uma pessoa, em virtude de sua especial capacidade de fato.

Cumpre definir estado e situação, para o perfeito entendimento do conceito de autoridade.

Estado da pessoa é a conjuntura, reconhecida pelo Direito, na qual a pessoa se encontra.

O Direito reconhece quatro espécies de estados: os estados políticos, os estados familiares, os estados físicos e os estados profissionais.

Os estados políticos das pessoas são os de nacional e de estrangeiro, sendo que o estado de nacional pode ser estado de brasileiro nato e estado de brasileiro naturalizado.

Os estados familiares das pessoas são os de solteiro, casado, viúvo, desquitado, pai, filho legítimo, ilegítimo, legitimado, natural, adotado; parente ascendente, descendente, sobrevivente, colateral; parente sanguínio, parente afim, e os outros estados decorrentes das chamadas relações de família.

Os estados físicos das pessoas são os estados decorrentes da idade delas (maior de idade, menor de idade) e de sua saúde mental (normal, demente, pródigo, etc.).

Os estados profissionais das pessoas são os decorrentes do exercício usual de seu trabalho, como os estado de empregador, 
de empregado estável e não estável, de trabalhador autônomo e avulso, de empregado doméstico e rural; de agricultor, comerciante, industrial; de profissional liberal, de professor titulado, de banqueiro e bancário, de ferroviário, telegrafista, operador cinematográfico, estivador, embarcadiço, aviador, etc..

O estado de uma pessoa não é o mesmo que a situação dela.

Situação é a posição em que a pessoa se encontra, relativamente a outra ou outras, de acordo com as determinações do Direito (excluídas as situações familiares e profissionais, que são consideradas estados, como se acaba de ver).

São situações, por exemplo, as posições de ausente, tutor, curador, administrador, gestor, possuidor, proprietário, condômino, enfiteuta, foreiro, senhorio, usufrutuário, usuário, locador, inquilino, vizinho, credor e devedor, cessionário, doador e donatário, mutuário, depositante e depositário, mandante e mandatário, editor, sócio, parceiro, segurador e segurado, fiador, promitente, testador, herdeiro, legatário, testamenteiro, inventariante; gerente e diretor de pessoas jurídicas; chefe e diretor de repartições públicas ; prefeito municipal, secretário e ministro de Estad.o, governador de Estado e presidente da República; vereador, deputado, senador; delegado de polícia, promotor público, juiz.

\section{$\S 3$.}

Em razão de seu estado ou de sua situação - em razão de suas especiais capacidades de fato -, pode uma pessoa ter o poder de se impor a outras, nos termos da lei. Esse poder é que, nos domínios do Direito, se denomina autoridade.

Neste sentido, é que o Código Civil, em seu Art. 458, emprega a palavra autoridade: "A autoridade do curador estende-se à pessoa e bens dos filhos do curatelado, nascidos, ou nascituros". Igualmente, em seu Art. 1.690, parágrafo único: "Não pode, porém, o legatário entrar, por autoridade própria, na posse da coisa legada".

Os próprios detentores do referido poder recebem o nome de autoridades. Assim, por exemplo, são autoridades, dentro dos círculos de suas respectivas influências, o pai, o tutor, o testamenteiro, o inventariante, o empregador, o gerente, o administrador, o diretor, o chefe, o prefeito, o secretário e o ministro de Estado, o governador e o Presidente da República, o deputado e o senador, o delegado de polícia, o promotor público, o juiz. Por analogia, os profissionais de carreira, costumam ser tidos como autoridades, na execução dos atos próprios de seus respectivos ofícios. 
Com tal sentido, é que a Constituição, em seu Art. 12, § $3 .^{\circ}$, emprega a palavra autoridade: "Cessados os motivos da intervenção, as autoridades afastadas de seus cargos a eles voltarão, salvo impedimento legal". E, também, em seu Art. 153: “\$22. (.. ) Em caso de perigo público iminente, as autoridades competentes poderão usar da propriedade particular, assegurado ao proprietário indenização últerior". "§ 27. Todos podem reunir-se sem armas, não intervindo a autoridade senão para manter a ordem".

No mesmo sentido, o Código Civil emprega a palavra autotoridade, no Art. 28: "Para se poderem alterar os estatutos da fundação, é mister: I. (...). II. ( . . ). III. Que (a alteração) seja aprovada pela autoridade competente".

$$
\S 4 \text {. }
$$

Autoridade-poder é um poder que se funda, necessariamente, em determinadas capacidades especiais do agente.

Autoridade-pessoa é o agente que, em virtude de seu estado ou de sua situação, possui determinadas capacidades especiais, que lhe conferem o referido poder.

Não são autoridades - ou, melhor, não agem como autoridades - os agentes enquanto simples executantes de atos que independem de capacidade específica, isto é, enquanto simplesmente empregam suas capacidades comuns.

Não agem como autoridades - embora possam ser autoridades, em outras ocasiões - as pessoas em geral, ao usarem suas capacidades comuns, como, por exemplo, as capacidades de ir e vir, de casar e constituir família, de estabelecer residência, de trabalhar, de comprar e vender, de abrir conta bancária, de viajar, de lavrar testamento.

Somente são autoridades as pessoas que, em razão de seu estado ou de sua situação, possuem capacidades de fato especiais, que lhes conferem, de acordo com o Direito, o poder de se impor a outras.

$$
\S 5 .
$$

Em muitos casos, uma autoridade pode estender seu poder a quem não seja autoridade, ou não seja autoridade da mesma qualificação ou categoria. Pode uma autoridade delegar seu poder. 0 era.

Com esse ato, a autoridade torna autoridade quem não

Este, precisamente, é o ato de autorizar.

Tal ato constitui uma delegacão de autoridade. 
É evidente que esse ato só pode ser ato de quem é autoridade. Só quem tem autoridade pode delegar autoridade. Só pode autorizar a fazer alguma coisa quem tem autoridade para fazer essa mesma coisa.

Autorizar, em verdade, é o ato pelo qual uma autoridade, credenciada para a produção de determinados atos, credencia outra pessoa, para produzir, em seu lugar, a mesma espécie de atos.

$\mathrm{O}$ ato de autorizar se chama autorização. Também se chama autorização a permissão dada a uma pessoa, para proceder como autoridade.

A autorização, como ato de autorizar, concede a alguém uma autorização, como permissão para desempenhar função de autoridade.

Assim, por exemplo, o proprietário, que é autoridade em seus domínios, concede, ao locatário, autorização para usar e gozar a coisa alugada (Código Civil, Art. 1.183) ; ao enfiteuta, autorização para exercer o domínio útil do imóvel (Código Civil, Art. 678) ; ao administrador, autorização para dar seus bens em comodato (Código Civil, Art. 1.248). O mandante, como autoridade, concede ao mandatário, autorização para, em seu nome, praticar atos, ou administrar interesses (Código Civil, Art. 1.288). O credor, que é autoridade para receber e cobrar o que lhe é devido, concede a seu representante autorização para agir, em seu nome, junto ao devedor (Código Civil, Art. 934).

$\mathrm{O}$ Governo da União concede, a fabricante particular, autorização para produzir material bélico (Constituição, Art. 8. ${ }^{\circ}$, VII) ; a uma empresa de transportes, autorização para explorar as vias de comunicação que transponham os limites de Estado ou Território (Const., Art. 8., XV). O Congresso Nacional, que é a autoridade representativa da Nação, concede autorização ao Presidente da República, para declarar a guerra e fazer a paz (Const., Art. 44, II).

\section{$\S 6$.}

Toda autorização é permissão, mas nem toda permissão é autorização.

A autorização é somente a permissão dada por autoridade. Ela resulta sempre, como já foi dito, de uma delegação de autoridade. Uma pessoa só tem autorização nos casos em que uma autoridade nela delegou seus poderes específicos.

A permissão, porém, não resulta, necessariamente, de uma delegação de poderes. Ela pode não ser mais do que uma licen$c ̧ a$, conforme o Direito, para a prática de um ato, ou de uma 
espécie ou série de atos, sem implicar extensão da autoridade de uma pessoa à outra.

A permissão dada ao locatário, para usar e gozar o imóvel, é mais do que uma simples permissão. É uma permissão qualificada, ou seja, uma autorização: uma autorização concedida pelo proprietário, porque ao proprietário é que pertence, primordialmente, o uso e gozo de seus bens. Só com autorização dele, pode outra pessoa usá-los e gozá-los.

A permissão dada a uma pessoa, para atravessar um imóvel, não é uma autorização, porque o proprietário do imóvel, ao conceder a referida licença, não delega, em ninguém, sua autoridade de proprietário. O que faz é, apenas, consentir na simples passagem da pessoa pelo imóvel. Ao contrário de delegar sua autoridade de proprietário, ele a utiliza, no ato de dar a licença.

Aliás, tudo que não estiver proibido pelo Direito, o Direito permite. São permitidos pelo Direito os usos de todas as capacidades humanas, com excepção dos usos que o próprio Direito proíbe.

Mas tais permissões, em regra, não são autorizações, porque não resultam de nenhuma delegação de autoridade.

$$
\S 7 \text {. }
$$

No Direito brasileiro, o substantivo autorização e 0 verbo autorizar são freqüentemente empregados com impropriedade. Em leis numerosas, que não se referem a qualquer espécie de delegação de autoridade, as referidas palavras são usadas sem nenhum cabimento. No seu lugar, dever-se-iam empregar as palavras permissão e permitir.

$\hat{E}$ o que acontece nos seguintes exemplos:

a) Constituição, "Art. 44. É da competência exclusiva do Congresso: ( . .) III - autorizar o Presidente e o Vice-Presidente da República a se ausentarem do País". Note-se que, no n. ${ }^{\circ}$ II do mesmo artigo, a palavra autorizar está empregada corretamente: "II autorizar o Presidente da República a declarar a guerra e a fazer a paz". O Congresso, que é a autoridade representativa da Nação, não pode autorizar ninguém a se ausentar do País, porque a Nação e o Congresso não têm capacidade, nem autoridade, para se ausentarem do País. O que o Congresso pode fazer é permitir que o Presidente e Vice-Presidente da República se ausentem. Mas a Nação tem autoridade para declarar a guerra e a fazer a paz; pode, pois, 
delegá-la no Congresso, que, por sua vez, a pode delegar no Presidente da República.

b) Constituição, "Art. 81. Compete privativamente ao Presidente da República: ( . .) XVIII - autorizar brasileiros a aceitar pensão, emprego ou comissão de governo estrangeiro". O Presidente pode permitir que brasileiros aceitem pensão, emprego ou comissão de governo estrangeiro, mas não pode autorizá-los a fazê-lo, porque o Presidente não pode autorizar o que ele próprio não está autorizado a fazer.

c) Código Civil, "Art. 180. A habilitação para casamento faz-se perante o oficial do registro civil, apresentando-se os seguintes documentos: (...) III. Autorização das pessoas sob cuja dependência legal estiverem, ou ato judicial que a supra". Para casar, não é preciso que o nubente seja uma autoridade. Não é preciso, pois, que ninguém lhe confira essa autoridade, por meio de uma autorização. Aliás, as pessoas, sob cuja dependência o nubente pode se encontrar, não possuem essa autoridade e, portanto, não a podem delegar. $O$ que a lei realmente exige não é uma autorização, mas uma permisssão.

d) Código Civil, "Art. 293. Os imóveis dotais não podem, sob pena de nulidade, ser onerados, nem alienados, salvo em hasta pública, e por autorização do juiz competente, nos casos seguintes (...)". O juiz não pode autorizar ninguém a onerar ou alienar bens dotais, porque ele próprio não tem autorização para onerá-los ou aliená-los. Aqui, também, o que a lei realmente exige não é uma autorização, mas uma permissão do juiz.

e) Código Civil, "Art. 322. A sentença do desquite autoriza a separação dos cônjuges (...)". O juiz, ao dar sua sentença, não está delegando autoridade; não está praticando o ato de autorizar. Logo, a sentença não autoriza os conjuges a se separarem. A sentença permite a separação. Aliás, para se separarem, os cônjuges não precisam de autoridade. $\mathrm{O}$ de que necessitam é, apenas, da permissão judicial.

f) Código Civil, "Art. 386. (Os pais) Não podem, porém, alienar, hipotecar, ou gravar de onus reais, os imóveis dos filhos ( . . ), exceto por necessidade, ou evidente utilidade da prole, mediante previa autorização do juiz". É evidente que o juiz, não tendo autoridade 
para alienar, hipotecar, ou gravar de onus reais, os imóveis dos filhos de outrem, não pode delegar essa autoridade em ninguém, isto é, não pode autorizar os pais a alienar, hipotecar ou gravar de ônus reais, imóveis pertencentes aos filhos. $O$ que ao juiz compete é dar ou negar permissão, para tais operações.

g) Código Civil, "Art. 427. Compete-lhe (ao tutor), também, com autorização do juiz: I. Fazer as despesas necessárias com a conservação e o melhoramento dos bens (do menor sob tutela) (...)". O juiz pode dar permissão ao tutor, para fazer as referidas despesas, mas não lhe pode dar autorização, porque o juiz, não tendo autoridade para fazê-las, está na impossibilidade de dar o que não possui.

h) Código Civil, "Art. 802. Resolve-se o penhor: ( . .) IV - Dando-se a adjudicação, a remição, ou a venda amigável do penhor, se a permitir expressamente o contrato, ou for autorizada pelo devedor". O devedor não tem autoridade para proceder à venda amigável do penhor. Logo, não pode delegar em ninguém essa mesma autoridade. $\mathrm{O}$ que o devedor pode fazer é permitir a referida venda, consentir que ela se efetue, dar-lhe sua anuência.

i) Código Civil, "Art. 1.744. Além das causas mencionadas no Art. 1.595, autorizam a deserdação dos descendentes por seus descendentes: I - Ofensas físicas. II - Injúria grave. III - ( . . )". É obvio que ofensas e injúrias não são titulares de autoridade e, portanto, não têm possibilidade de autorizar. $\mathrm{O}$ que o Código quer dizer é que ofensas e injúrias são justas causas, para a deserdação dos descendentes por seus ascendentes.

j) Lei n. $0^{\circ} 4.121$, de 27-08-1962 (Dispõe sobre a situação jurídica da mulher), IV: "Art. 242. A mulher não pode, sem autorização do marido: I - praticar os atos que este não poderia sem consentimento da mulher". Nem a mulher, nem o marido, isoladamente, tem autoridade para a prática dos atos, cuja validade depende de legitimação, ou seja, do consentimento do outro cônjuge. $O$ de que a mulher precisa, pois, para a prática de tais atos, não é a autorização do marido, mas seu consentimento ou permissão, exatamente como, para praticar a mesma espécie de atos, o marido precisa do consentimento ou permissão da mulher. 
k) Decreto n. 24.643, de 10-07-1934 (Código de Águas), "Art. 43, § $1 .^{\circ}$ (...) "a autorização não confere, em hipótese alguma, delegação de poder público ao seu titular". Evidentemente, nenhuma autorização "confere delegação de poder", pois toda autorização é uma delegação de poder. Em Direito Administrativo, todas as autorizações são, necessariamente, delegações de poder público. Ao dar uma autorização, um órgão do poder público delega sua autoridade (ou parte dela) a outro órgão do poder público, ou a qualquer entidade com capacidade de assumi-la. Não havendo delegação de autoridade, não há autorização, em hipótese alguma. $\mathrm{O}$ que pode haver é permissão, licença, concessão.

1) Ato Institucional N. ${ }^{\circ}$ 5, de 13-12-1968: "O Presidente da República Federativa do Brasil, ouvido o Conselho de Segurança Nacional, ( ) Resolve editar o seguinte Ato Institucional: ( . .) Art. $2^{\circ}, \S 10^{\circ}$ Decretado o recesso parlamentar, o Poder Executivo correspondente (sic) fica autorizado a legislar em todas as matérias e exercer as atribuições previstas nas Constituições ou na Lei Orgânica dos Municípios". Este famoso texto, pelo qual o Presidente da República autoriza o Presidente da República a legislar, dispensa qualquer comentário.

\section{$\S 8$.}

As permissões (inclusive as autorizações) somente são jurídicas quando concedidas por meio de normas jurídicas. Observe-se que as permissões são concedidas pelas entidades que as podem conceder (pessoas naturais, pessoas jurídicas, a sociedade global, grup.os sociais), e não pelas próprias normas. Mas tais permissões não têm validade jurídica se não forem dadas por meio de normas jurídicas.

A propósito, o Código Civil dispõe: "Art. 132. A anuência, ou a autorização de outrem, necessárias à validade de um ato, provar-se-á do mesmo modo que este, e constará, sempre que ser possa, do próprio instrumento".

Se não constar "do próprio instrumento", a permissão só tem validade jurídica se concedida por meio de lei, ou por forma não defesa em lei. Nesta última hipotese, a permissão também é concedida por meio de norma jurídica, porque a "forma não defesa em lei" (Cód. Civ., Art. 82) é forma admitida pela lei e, portanto, forma com validade jurídica (forma equivalente a alguma espécie de norma jurídica). O próprio Código Civil reconhece tal validade, em seu artigo 129: "A validade das 
declarações de vontade não dependerá de forma especial, senão quando a lei expressamente a exigir".

A autorização dada ao locatário, para usar e gozar do imóvel, é uma permissão jurídica, porque é concedida por meio das normas jurídicas que constam do próprio instrumento da locação. A permissão dada aos nubentes, de estipular, antes do casamento, quanto a seus bens, o que lhes aprouver, é uma permissão jurídica, porque é concedida por meio da norma jurídica do artigo 256 do Código Civil. A autorização dada a uma pessoa, para que pernoite na propriedade de outra, é uma permissão jurídica, porque é concedida por meio de proposições orais ou escritas, que constituem normas com validade jurídica, uma vez que são aplicações do que se acha disposto nos artigos do Código Civil, relativos ao empréstimo sob forma de comodato (Arts. 1.248 e seguintes).

A autorização dada ao empregado, pelo gerente de sociedade, para que desvie mercadorias da empresa, não é permissão jurídica, porque é concedida por meio de proposições que não constituem normas com validade jurídica.

É jurídica a autorização dada pela sociedade global a toda pessoa lesada, em conseqüência de violação de norma jurídica, para que exerça, pelos meios legais, coação sobre o violador, a fim de fazer cessar ou de obstar a violação, ou de obter, do mesmo violador, reparação pelo mal que ele causou. Essa autorização é jurídica porque é concedida, fundamentalmente, por meio do artigo 75 do Código Civil: "Art. 75. A todo direito corresponde uma ação, que o assegura".

\section{$\S 9$.}

As permissões dadas por meio de normas jurídicas podem ser explícitas ou implícitas. São explícitas as permissões que as normas jurídicas mencionam expressamente. São implícitas as permissões que as normas jurídicas não mencionam expressamente, mas cujo uso é por elas regulado, ou por elas assegurado pela proibição do que o impede, ou, simplesmente, por elas não é proibido. Em outras palavras, são implícitas as permissões de fazer, de não fazer, de ter e de não ter o que a norma jurídica não proibe que se faça ou que não se faça, que se tenha ou que não se tenha.

São exemplos de permissões explícitas as seguintes: permissão dada ao maior de idade, para praticar todos os atos da vida civil (Código Civil, Art. $9^{\circ}$ ) ; permissão dada aos nubentes, para estipular, antes de celebrado o casamento, quanto a seus bens, o que lhes aprouver (Código Civil, Art. 256); permissão dada à mulher que exercer profissão lucrativa, para 
praticar todos os atos inerentes ao seu exercício e à sua defesa (Código Civil, Art. 246, com a redação dada pela Lei N. ${ }^{\circ} 4.121$, de 27-08-1962) ; permissão dada ao herdeiro, de requerer a partilha, ainda mesmo quando isto lhe tenha sido defeso pelo testador (Código Civil, Art. 1.772).

São exemplos de permissões implícitas as seguintes: permissão para estabelecer domicílio (implícita nos Arts. 31 a 42 do Código Civil, que, embora não a mencionem, dispõem sobre o domicílio) ; permissão para casar (implícita nos Arts. 180 a 232 do Código Civil, que, embora não a mencionem, dispõem sobre as formalidades, os impedimentos, a celebração, as provas, as nulidades e os efeitos jurídicos do casamento); permissão para ir e vir livremente (implícita no Art. 153, §§ 12 e 20 da Constituição do Brasil, que, embora não a mencione, proibe a prisão senão em flagrante delito ou por ordem escrita da autoridade competente, e manda conceder habeas corpus sempre que alguém sofrer violência ou coação em sua liberdade de locomoção; implícita, igualmente, nos Arts. 152 e 154 do Código Penal, segundo os quais são crimes as ações de constrangimento ilegal, de seqüestro e de manter pessoa em cárcere privado).

\section{$\S 10$.}

Todas as permissões, dadas por meio de norma jurídica, tanto as explícitas como as implícitas, se fundam, em última análise, no Princípio da Legalidade, princípio básico do Direito, síntese da razão de ser de toda e qualquer ordenação jurídica, e que se formula nos seguintes termos: "Ninguém deve ser obrigado a fazer ou deixar de fazer alguma coisa senão em virtude da norma jurídica". (Constituição do Brasil, Art. $153, \S 2 .^{\circ}$ ).

Este princípio se converte no seguinte: A todos é permitido fazer o que a norma jurídica não proibe, e não fazer o que a norma jurídica não manda fazer.

Constitui crime de constrangimento ilegal o ato de "constranger alguém, mediante violência ou grave ameaça, ou depois de lhe haver reduzido, por qualquer outro meio, a capacidade de resistência, a não fazer o que a lei permite, ou a fazer o que ela não manda" (Código Penal, Art. 146).

$$
\S 11 .
$$

As permissões explícitas e implícitas, dadas por meio de normas jurídicas, são os chamados Direitos Subjetivos.

$\mathrm{Na}$ ciências e na prática do Direito, importantíssima é a verificação de que o Direito Subjetivo não é faculdade, mas permissão para o uso de faculdades. 
A noção tradicional de que o Direito Subjetivo é faculdade, a "facultas agendi", se tornou insustentável, a partir do momento em que a verdadeira noção de faculdade se introduziu na Ciência do Direito.

Parece oportuno recordar que os filósofos ensinam, desde Aristóteles, que as faculdades são potências: potências que dispõem um ser a agir. Uma faculdade, dizem os filósofos, não é ato, mas a aptidão ou potência para produzir o ato.

Uma potência ou faculdade é a possibilidade de ser, e, portanto, ainda não é o ser feito, o ser acabado. A possibilidade de ser, o ser em potência, antecede o ser em ato.

Embora não seja um ser em ato, a faculdade já é alguma coisa. Ninguém diria que uma faculdade é nada. Uma aptidão não é coisa nenhuma. Não sendo nada, é ser: é ser em potência, é ser como aptidão, como aptidão de ser.

Ora, uma potência, faculdade ou aptidão se pode aplicar a se fazer ato. Pode atualizar-se, tornar-se ato. $\mathrm{O}$ ser em potência pode passar a ser em ato.

Neste caso, a faculdade ou potência se perfaz: perfaz-se no ato para o qual se dispunha.

O perfazimento da potência é o ato, em que ela se realiza. E este é o motivo pelo qual os filósofos dizem que $o$ ato é a perfeição da potência.

Segundo Aristoteles, a passagem da potência ao ato é o que constitui o movimento.

As faculdades do homem são potências próprias do ser humano - potências que pertencem ao homem, pelo fato do homem ser o ser que ele é. São aptidões do homem, independentemente de qualquer implicação ou pressuposto de ordem jurídica. São aptidões próprias do homem. E por serem próprias, são propriedades dele.

As faculdades do homem são propriedades do homem. Mas não são propriedades, no sentido jurídico deste termo. A expressão propriedade está sendo empregada para designar, apenas, o que é próprio. Neste sentido, é que as faculdades do homem são propriedades dele, como, também, são propriedades suas as aptidões de ver, pensar, falar. São propriedades do homem, como a aptidão de voar é propriedade do pássaro.

Inúmeras são as faculdades do ser humano. Mas o que é preciso salientar é que o emprego ou uso dessas faculdades pode ser permitido ou pode ser proibido. 
As permissões para o uso, das faculdades humanas, quando são dadas por meio de norma jurídica, constituem, precisamente, os Direitos Subjetivos.

Os Direitos Subjetivos, portanto, não são as faculdades do homem, mas as permissões juridicas para o uso dessas faculdades.

Quem tiver permissão jurídica (permissão ou autorização dada por meio de norma jurídica) para usar uma de suas faculdades, tem o direito de usar essa faculdade. Em termos mais positivos, quem tiver permissão jurídica para fazer ou ou não fazer alguma coisa tem o direito de fazê-la ou de não fazê-la. Quem não tiver tal permissão (ou autorização, se for o caso) não tem esse direito, embora possa ter a faculdade de fazê-la ou não.

Não há quem não tenha, por exemplo, a faculdade de praticar atos ilícitos (civis ou criminais), mas ninguém tem o direito de praticá-los, porque a ninguém é dada permissão jurídica de usar a referida faculdade.

Não há quem não tenha a faculdade de ser proprietário, e de usar, gozar e dispor de bens. Mas esta faculdade não é o direito de propriedade. O direito de propriedade não é mera aptidão de ser proprietário, mas a permissão, concedida a quem é proprietário, permissão dada por meio do Art. 524 do Código Civil, para usar, gozar, e dispor de seus bens. Essa permissão só é concedida a quem é proprietário. Logo, só o proprietário tem o direito subjetivo de propriedade (direito de usar, gozar e dispor de bens), embora todos tenham a faculdade de ser proprietários.

A mãe, que contrai novas núpcias, não perdia a faculdade de exercer o pátrio poder, quanto aos filhos do leito anterior, mas perdia o direito de exercê-lo, porque a lei lhe negava a permissão de usar a referida faculdade. O direito se extinguia, por força da proibição legal, embora a faculdade permanecesse. Tornando a viuvar, a mãe recuperava o direito que havia perdido, porque a lei lhe dava permissão de usar, novamente, sua faculdade de exercer o pátrio poder (Código Civil, Art. 393). A Lei $n .^{\circ} 4.121$, de 27-8-1962, alterou a disposição deste artigo, e estabeleceu que "a mãe que contrai novas núpcias não perde, quanto aos filhos do leito anterior, os direitos ao pátrio poder, exercendo-os sem qualquer interferência do marido."

Pode uma pessoa ter a faculdade de vender imóvel de sua propriedade, e não ter o direito de fazê-lo, por não conseguir, para a operação, a necessária anuência de quem de direito. 
Todos têm o direito de ir e vir, porque a todos é concedida, por meio da ordenação jurídica, a permissão para se locomover livremente. Mas, se uma pessoa, por algum motivo, não tiver essa permissão (estiver proibida de ir e vir livremente), não terá, em verdade, o direito de ir e vir, embora conserve, intacta, a sua faculdade de se locomover à vontade. É o que acontece, por exemplo, com quem esteja sujeito à providência da prisão domiciliar sob palavra, ou à medida de segurança de exílio local.

Quem estiver condenado à pena de reclusão em prisão aberta, possui, evidentemente, a faculdade de transpor os limites geográficos do presídio, e de evadir-se. Mas não tem o direito de fazê-lo, porque não tem permissão jurídica de sair do presídio.

Sem permissão jurídica, não há Direito Subjetivo.

Dentro da sociedade, quem pratica ato, sem permissão jurídica (explícita ou implícita), pratica ato ilícito.

As permissões jurídicas, explícitas ou implícitas, são os Direitos Subjetivos.

Em suma, Direito Subjetivo não é faculdade de agir não é "facultas agendi" —, mas é a permissão, dada por meio de norma jurídica, para usar a faculdade de agir. É a permissão jurídica para o uso da "facultas agendi"

O Direito Subjetivo se define: Permissão dada por meio de norma jurídica.

O termo permissão inclui, em seu conceito, as autorizações. $\S 12$.

Para bom entendimento do que se vem expondo, cumpre acrescentar que há certa afinidade entre as faculdades do ser humano e as suas capacidades. Aliás, todas as capacidades são faculdades. Nem todas as faculdades, porém, são capacidades.

Capacidade é a faculdade de adquirir direitos subjetivos (capacidade de direito) e a faculdade de usar esses direitos (capacidade de fato).

Mas, faculdades existem que não são capacidades, entendendo-se este termo em seu sentido jurídico.

Não são capacidades, as faculdades de praticar ato ilícito.

Note-se que as faculdades se prendem à personalidade, e independem do Direito. As capacidades se prendem à ordenação jurídica, e a ela devem sua existência e graduação. 
As permissões (inclusive as autorizações) dadas por meio de normas jurídicas, e que constituem os Direitos Subjetivos, são permissões para o emprego das capacidades das pessoas.

$\S 13$.

O Direito permite o que o Direito não proibe.

Inúmeras, portanto, são as permissões, explícitas e implícitas, dadas por meio de normas jurídicas. Inúmeros os Direitos Subjetivos das pessoas.

São Direitos Subjetivos das pessoas as permissões de fazer e não fazer, de ter e não ter tudo aquilo que é concedido, expressamente, por meio de norma jurídica, e, também, tudo aquilo que a norma jurídica, expressamente, não proibe.

Quando uma pessoa, em condições normais, é impedida de usar algum de seus Direitos Subjetivos, uma norma jurídica está sendo violada. Pois, todos os Direitos Subjetivos são permissões dadas por meio de normas jurídicas.

Ora, ninguém pode ser obrigado a se conformar com os efeitos da violação de uma norma jurídica. Ninguém pode ser obrigado a permanecer sofrendo os efeitos da ação ilícita de outrem; a sujeitar-se a uma situação prejudicial, imposta em desobediência ao que manda a norma jurídica.

Nesta matéria, o já citado Princípio da Legalidade é lei soberana.

Em consequiência, a pessoa prejudicada - o lesado pela violação da norma jurídica - tem a permissão de reagir contra a ação que a lesou. Tem o direito de coagir o violador a cumprir a norma violada, ou a reparar o dano, causado pela infringência.

Essa permissão é um autêntica autorização. É uma autorização dada pela coletividade ou pelo grupo social, em que vigora a norma violada.

O motivo da autorização está no fato de que não pode interessar ao ser humano a violação livre das normas jurídicas. Uma tal violação, se consentida como prática normal e permanente, ocasionaria a destruição das instituições, o desmoronamento das estruturas sociais. O ser humano se veria privado de sua primeira condição de sobrevivência, de seu mais nobre instrumento, ou seja, da sociedade organizada, sem a qual ele não se consegue manter. Estas observações valem tanto para a sociedade global, como para os grupos sociais, de que a sociedade global é feita. O que se quer, pois, é que as normas jurídicas sejam cumpridas. 
Então, para assegurar a permanência e a eficácia das instituições, a sociedade e os grupos sociais delegam a todos quantos forem lesados pela violação das normas jurídicas, o poder de exigir o cumprimento delas ou a reparação do dano causado pela infringência.

Isto significa, na prática, que a violação das normas jurídicas tem como conseqüência uma autorização, que é dada pela comunidade, aos que a violação prejudicou.

De fato, uma vez violada a norma jurídica, a comunidade autoriza quem for lesado pela violação, ou quem for um provável lesado por previsível e iminente violação, a exercer, pelos meios legais, coação sobre o violador (violador efetivo ou provável), a fim de fazer cessar ou de obstar a referida violação, ou de obter, do mesmo violador, a justa reparação pelo mal que a infringência causou. Se a infringência constitui crime, a comunidade autoriza o órgão do Poder Público, que a representa, ou a própria vítima direta, a exigir que o delinquente seja processado e sujeito às penas da lei.

\section{$\S 14$.}

Disto se conclui que os Direitos Subjetivos são, fundamentalmente, de dois graus.

Os do primeiro grau são os Direitos Subjetivos comuns $d a$ existência, como, por exemplo, os direitos de ter um nome, de ir e vir, de manifestar o pensamento, de estabelecer residência e ter domicílio, de constituir família e exercer o pátrio poder, de trabalhar ou não trabalhar, de ser empregador ou empregado, de ser proprietário, de vender e comprar, de doar, de fazer testamento.

Os Direitos Subjetivos do segundo grau os Direitos Subjetivos de proteger os Direitos comuns da existência, isto é, os Direitos de defender os Direitos, com a regular aplicação das sanções legais, por meio da coação jurídica.

De fato, o Direito Subjetivo compreende duas espécies de permissões, a saber:

1. as permissc̃es, dadas por meio das normas jurídicas, de fazer, não fazer, ter e não ter o que não pode ser impedido ou tirado, sem violação de norma jurídica;

2. as autorizações, dadas por meio de normas jurídicas, de proteger o uso dos Direitos Subjetivos.

As primeiras são permissões de simplesmente fazer ou não fazer isto ou aquilo, de ter ou não ter isto ou aquilo, sem exigências, nem reclamações. 
As segundas são autorizações de resistir contra a ilegalidade, de fazer cessar ou obstar ato ilícito, de reclamar reparação pelo mal que o ato ilícito causou, e, em caso de crime, de impor pena ao delinqüente.

\section{$\S 15$.}

As autorizações que constituem os Direitos Subjetivos de segundo grau são de capital importância na conceituação da norma jurídica.

Tais autorizações somente se concretizam quando a norma jurídica é violada. E somente são concedidas quando a norma violada é jurídica.

Se a norma violada é jurídica, sempre haverá uma pessoa autorizada a exigir o cumprimento dela, ou a reparação do mal causado pela infringência. Se a norma violada não for jurídica, ninguém terá essa autorização.

Seja, por exemplo, a norma: "Praticarás a caridade". Se alguém não praticar a caridade, estará violando a citada norma. Prejudicados estarão os que se beneficiariam dessa caridade. Mas ninguém estará autorizado a exigir o cumprimento da norma violada. O mendigo de braço estendido, chapéu na mão, não pode exigir a esmola que lhe foi negada. A norma citada não é uma norma jurídica.

Seja, por exemplo, a norma: "Todo aquele que recebeu o que não lhe era devido fica obrigado a restituir". Se aquele, que recebeu o indevido, não restituir, prejudicado estará quem se beneficiaria com a devolução. Mas a ação não praticada (a restituição) é uma ação exigível. E o lesado (o pagador do indevido) estará autorizado a exigir o cumprimento da norma violada. Diferentemente da primeira, esta norma é jurídica.

São jurídicas, as normas cuja violação dá ensejo a que a coletividade conceda ao lesado a referida autorização. E esta autorização é concedida porque o cumprimento de certas normas é considerado a necessária condição para que a sociedade se realize como instrumento a serviço do homem. Precisamente porque seu cumprimento é assim considerado, é que tais normas se diferenciam das demais, e se especificam como normas jurídicas. Os lesados, ao receberem a referida autorização, ficam em condições de defender seus interesses. $\mathrm{E}$ ao fazê-lo, exigirão o cumprimento das normas violadas.

Pelo simples fato de existirem e de estarem vigentes, as normas jurídicas manifestam a vontade da coletividade (vontade real ou presumida). Manifestam, antes de tudo, o mandamento, que, por elas, se exprime; e manifestam, também, 
embora tacitamente, a advertência de que, se violadas, os lesados estarão autorizados, pela coletividade, a exigir o seu cumprimento, ou a reparação do mal causado pela violação.

Essa advertência é tácita, sim, em cada norma jurídica, mas está expressa, com todas as letras, no já citado Art. 75 do Código Civil: "A todo o direito corresponde uma ação que o assegura". E expressa, também, na própria Constituição, em seu capítulo sobre os direitos e garantias individuais: "Art. 153, § $4 .^{\circ}$. A lei não poderá excluir da apreciação do Poder Judiciário qualquer lesão de direito individual".

Em cada norma jurídica, está latente o Princípio da Legalidade.

Por constituírem um mandamento e por terem sua eficácia assegurada pela autorização dada aos que forem lesados pela sua violação, a norma jurídica se define: Imperativo autorizante.

As normas jurídicas formam uma espécie de normas, incluida no gênero das leis éticas, gênero este que é o das normas em geral. De fato, as normas jurídicas se diferenciam, especificamente, das normas não jurídicas. $\mathrm{E} o$ que as diferencia é uma qualidade que lhes é própria e exclusiva. Tal qualidade é designada pelo adjetivo autorizante.

Todas as normas são imperativas, porque, de uma ou outra maneira, todas as normas são mandamentos. Mas somente as normas jurídicas são autorizantes.

Note-se, porém, que, na definição da norma jurídica, o adjetivo autorizante p.ossui sentido estrito e técnico. Nessa definição, a norma jurídica é qualificada de autorizante, porque nenhuma norma jurídica pode ser violada, sem que alguém fique autorizado a exigir o seu cumprimento ou o ressarcimento do dano, que a violação causou.

Em rigor, a coletividade é que é autorizante, porque ela é a autoridade capaz de conceder a referida autorização. Mas esta autorização é dada em defesa da norma jurídica. Ela não se verifica quando a norma violada não é jurídica. É uma autorização de tal maneira associada à norma jurídica, que uma não existe sem a outra. Precisamente por ser jurídica, a violação da norma acarreta essa autorização. E essa autorização é concedida precisamente porque a norma é jurídica. 
Se se diz que a norma é autorizante - quando, fundamentalmente, a coletividade é que o é - nada mais se faz do que simplificar a linguagem.

Em verdade, esta simplificação não falseia cousa nenhuma, porque nada desaconselha que a própria norma seja considerada autorizante, já que ela exprime a vontade da coletividade.

Aliás, na contínua luta pelo Direito, a norma jurídica é sempre considerada assim. O lesado, ao intentar ação, para defender o que julga ser seu, começa por invocar uma norma jurídica - aquela norma, em que seu interesse se funda, e que, por ter sido violada, o autoriza a reagir contra quem a infringiu. mento.

Sendo autorizante, toda norma jurídica é um autoriza-

O autorizamento da norma é causa da autorização, de que o lesado é titular. lesado.

Logo, o autorizamento é da norma. A autorização é do

$\S 16$.

Na terminologia que aqui está sendo empregada:

a) a palavra autorizamento designa a autorização enquanto propriedade da entidade autorizante, isto é, enquanto propriedade da coletividade ou de um grupo social, e, por extensão, enquanto propriedade $d a$ norma jurídica.

b) a palavra autorização designa a autorização enquanto propriedade da entidade que a recebeu, isto é, enquanto propriedade do lesado pela violação da norma jurídica.

\section{$\S 17$.}

Não se confunda autorizamento com atributividade.

É comum dizer-se, depois de LEON PETRAZYCKI, que a norma jurídica é a norma atributiva. Segundo esta teoria, a atributividade, que seria a diferença específica da norma jurídica, constitui a qualidade dessa norma de atribuir, a quem seria lesado pela violação da mesma, a faculdade de exigir o cumprimento dela, ou a de exigir, do violador, a competente reparação pelo mal a que a infringência deu causa.

A teoria da atributividade representou um grande progresso na descoberta da natureza da norma jurídica. Ela 
revelou uma realidade bem simples, mas muito importante: a realidade de que a coação, exercida sobre o violador da norma, não era uma propriedade da norma jurídica, mas ato praticado por quem a violação da norma lesou.

Com isto, a teoria da atributividade pôs por terra velhas e arraigadas convicções, como a de que a norma jurídica se define norma coativa, e a de que a coação e a coatividade pertencem à própria natureza dessa norma, constituindo seus caracteres distintivos e específicos, sendo o que a diferencia da norma não jurídica, ou seja, da norma destituída de coação e de coatividade.

Acontece, porém, que uma análise recente demonstrou não ser possível, também, aceitar a tese da atributividade das normas jurídicas. Estas normas, de certo, não são coativas; mas, igualmente, não são atributivas (Cfr. GoFFredo Telles JunIoR, O Direito Quântico, Cap. VI).

A norma jurídica não é atributiva (conferindo-se a este adjetivo o sentido que lhe é dado pela teoria da atributividade) por dois motivos essenciais.

Não é atributiva, primeiro, porque a norma jurídica não atribui a faculdade de coagir, uma vez que ela própria não possui essa faculdade. A norma jurídica, por si mesma, não tem, como é óbvio, possibilidade de coagir quem quer que seja. Ora, nenhuma entidade pode dar o que não tem. Logo, a norma jurídica não pode atribuir a ninguém uma faculdade que ela não possui.

Em segundo lugar, a norma jurídica não é atributiva porque a faculdade de coagir, não é atribuída ao lesado, uma vez que tal faculdade pertence ao lesado, por natureza. As faculdades humanas são potências próprias do homem, como a faculdade de voar é potência própria do pássaro. A faculdade dos homens de se coagirem uns aos outros é faculdade natural deles, independente de quaisquer normas. É faculdade que não decorre do Direito.

A norma jurídica não atribui ao credor, por exemplo, a faculdade de exigir o que lhe é devido. Tal faculdade, o credor a possui, com ou sem norma jurídica. É uma faculdade natural do ser humano. A norma jurídica se limita a autorizar o credor a fazer uso dessa faculdade; autoriza-o a exigir, pelos meios e formas legais, o pagamento do devido. Em suma, a norma jurídica é que autoriza o credor a exercer 
coação sobre o devedor, para deste obter aquilo a que o credor tem direito. E essa coação, quando assim autorizada, é ato lícito. E ato ilícito, quando o credor o pratica sem estar autorizado por norma jurídica.

Depreende-se, do que se acaba de demonstrar, que a norma jurídica não atribui faculdade. 0 que lhe é próprio é, unicamente, declarar, em nome da sociedade, que o lesado, para os fins legais, está autorizado a exercer sua faculdade de coagir.

A norma jurídica não é atributiva. Ela é autorizante. 